\title{
Model Sistem Dinamik Untuk Pengembangan Smart Economy (Studi Kasus: Kota Surabaya)
}

\author{
Andre Firmansyah dan Erma Suryani \\ Departemen Sistem Informasi, Fakultas Teknologi Informasi, Institut Teknologi Sepuluh Nopember \\ (ITS) \\ e-mail: erma.suryani@is.its.ac.id
}

\begin{abstract}
Abstrak-Kota Surabaya merupakan salah satu dari kota besar di Indonesia yang telah berkembang menuju Smart City. Surabaya memiliki perkembangan yang cukup pesat dalam bidang ekonomi. Data dari Badan Pusat Statistik kota Surabaya menunjukkan bahwa sampai tahun 2015 Produk Domestik Regional Bruto (PDRB) di kota Surabaya terus mengalami kenaikan. Hal ini menujukkan perekonomian di Surabaya begitu progresif. Oleh karena itu konsep Smart Economy perlu dikembangkan dengan baik untuk menghadapi dinamisasi perekonomian di kota Surabaya. Menurut ISO 37120 sebagai standar dari smart city, indikator utama ekonomi dalam smart city adalah jumlah pengangguran dan jumlah kemiskinan. Maka untuk mengembangkan smart economy, diperlukan analisis dalam pengembangannya berupa model simulasi smart economy. Nantinya akan dilakukan pemodelan terhadap faktor-faktor yang dapat mempengaruhi tingkat pengangguran dan jumlah kemiskinan di kota Surabaya. Adapun metode yang digunakan untuk mengembangkan model smart economy adalah sistem dinamik dengan pertimbangan bahwa model bersifat non linear dan dinamis. Analisis dilakukan dengan mempertimbangkan faktor ekonomi makro. Selanjutnya dilakukan skenariosasi struktur dan parameter. Dari skenario tersebut kemudian dilakukan studi komprehensif jangka panjang. Hasil dari pembuatan skenario struktur dan parameter didapatkan skenario terbaik. Skenario struktur terbaik yang paling dapat mengurangi rata-rata persentase penduduk miskin terhadap populasi adalah skenario struktur variabel investasi, yaitu sebesar $6.24 \%$. Sedangkan skenario parameter terbaik yang paling dapat mengurangi rata-rata persentase penduduk miskin adalah skenario optimistic, yaitu sebesar $5.62 \%$. Hasil penelitian ini dapat berkontribusi dalam pengembangan kebijakan untuk smart economy sebagai langkah kota Surabaya menuju smart city.
\end{abstract}

Kata Kunci: simulasi, sistem dinamik, kemiskinan, PDRB, pengangguran, smart city, smart economy.

\section{PENDAHULUAN}

$\mathrm{S}$ AAT ini pertukaran informasi yang cepat dan akurat sehingga bisa diakses secara real time dan terbuka telah menjadi kunci dari pembangunan suatu negara. Informasi tersebut nantinya dapat menjadi bahan pengukuran pemerintah dalam pengambilan keputusan dan eksekusi kebijakan. Salah satu bentuknya untuk lingkup kawasan kota adalah konsep kota cerdas atau smart city [1]. Smart city ini dapat mendukung pembangunan teknologi informasi di lingkup wilayah kota serta melakukan pembangunan yang cerdas dan bersifat independent yang membutuhkan partisipasi aktif dari masyarakatnya [2].
Surabaya merupakan salah satu kota di Indonesia yang sedang berproses menjadi smart city seutuhnya. Kota Surabaya sudah memperoleh penghargaan tingkat nasional hingga asia pasifik. Pada tahun 2011, Surabaya berhasil meraih tiga penghargaaan smart city yaitu pada kategori smart governance, smart living dan smart environment pada ajang Smart City Awards yang diadakan oleh majalah wartaekonomi [3]. Meski memperoleh penghargaan sebagai kota yang paling progressif dalam menerapkan smart city, menurut Walikota Surabaya, Tri Rismaharani bahwa salah satu kriteria keberhasilan dalam menerapkan kota cerdas adalah perekonomian yang baik dan memaksimalkan sumber daya dan potensi kota. Dalam hal ini $\mathrm{Bu}$ Tri Rismaharani menekankan tentang penerapan salah satu dimensi smart city yaitu smart economy [4].

Smart economy merujuk pada persaingan ekonomi seperti usaha mikro, kecil dan menengah, perdagangan dan industri, produktifitas, pasar buruh dan integrasi dengan pasar nasional maupun internasional [2]. Berdasarkan data Badan Pusat Statistik Kota Surabaya, kondisi perekonomian kota Surabaya terus mengalami dinamisasi pada beberapa sektor [5]. Beberapa sektor perekonomian makro yang mendukung tercapainya indikator smart economy adalah Produk Domestik Regional Bruto (PDRB), Tingkat Pengangguran Terbuka (TPT), dan Indeks Pembangunan Manusia (IPM) [6][7][8]. Ditambah lagi di kota Surabaya banyak bermunculan pelaku usaha yang nantinya juga turut andil mewarnai perekonomian di Surabaya dalam aspek enterpreneurship. Mayoritas Pelaku usaha di kota Surabaya bergerak dalam skala UMKM yang nantinya akan berdampak pada ketenagakerjaan dan tingkat pengangguran terbuka di kota Surabaya [6].

Kota Surabaya memiliki potensi perekonomian yang besar. Dukungan dari banyak sektor perekonomian yang mendukung Surabaya sebagai kota perdagangan dan industri. Surabaya berpotensi menjadi pusat konsentrasi industri dan pusat pengembangan Indonesia bagian timur di masa mendatang. Surabaya cukup kondusif dalam iklim usaha dan perdagangan dikarenakan sarana dan prasarana yang memadai. Salah satu indikator yang digunakan untuk melihat pembangunan sektor ekonomi adalah Produk Domestik Regional (PDRB). Berdasarkan PDRB menurut lapangan usaha di tahun 2015, sektor Perdagangan, Hotel dan Restoran berkontribusi paling besar dalam menyumbang Produk Domestik Regional Bruto (PDRB) yakni sebesar 48\% [9]. Sektor tersebut termasuk dalam sektor ekonomi tersier yang pembangunannya terus meningkat 
di kota Surabaya. Hal itu tidak terlepas dari program pemerintah yang mendukung berkembangnya iklim usaha dan tingkat konsumsi masyarakat kota Surabaya yang tergolong tinggi [10]. Tingkat Pengangguran Terbuka (TPT) menunjukkan angka yang fluktuatif naik turun dalam beberapa tahun. Rata-rata TPT kota Surabaya tahun 2001-2015 adalah 7.3\%. Meski fluktuatif, namun TPT kota Surabaya menunjukkan angka yang cenderung mengalami penurunan. Hal tersebut dipengaruhi oleh pertumbuhan penduduk yang mencari kerja lebih lambat daripada pertumbuhan penduduk angkatan kerja. Lalu untuk Indeks Pembangunan Manusia (IPM) kota Surabaya, berdasarkan data paling mutakhir yaitu tahun 2015 berada pada angka 79.47. IPM didapatkan dari penjumlahan 3 indikator utama yaitu indeks kesehatan, pendidikan dan standar hidup [9]. TPT dan IPM inilah yang nantinya akan mempengaruhi angka kemiskinan di kota Surabaya.

Berdasarkan Rencana Pembangunan Jangka Panjang Daerah (RPJPD) Kota Surabaya periode 2005-2025, Kota Surabaya memiliki misi mewujudkan perekonomian daerah berbasis potensi ekonomi lokal. Serta mewujudkan pola kerja sama yang sinergis dalam menciptakan perekonomian yang berkeadilan dan beretika. Untuk mewujudkan RPJPD tersebut, Kota Surabaya memiliki misi jangka menengah dalam Rencana Pembangunan Jangka Menengah Daerah (RPJMD) periode 2016-2021 dalam aspek ekonomi. Tiga poin misi RPJMD tersebut adalah memberdayakan masyarakat dan menciptakan kesempatan berusaha, mewujudkan Surabaya sebagai pusat penghubung perdagangan dan jasa antar pulau dan internasional, dan memantapkan daya saing usaha ekonomi lokal, inovasi produk dan jasa, serta pengembangan industri kreatif [11].

Menurut dokumen RPJMD periode 2016-2021, persentase kondisi awal terkait kajian/rekomendasi perekonomian yang termanfaatkan sebagai dasar kebijakan/keputusan masih dalam angka $0 \%$. Sehingga penelitian ini perlu dilakukan untuk mendukung program pengendalian pelaksanaan kebijakan kepala daerah [11].

Dengan terlaksananya penelitian ini diharapkan untuk dapat mengetahui skenario terbaik dari pengembangan model sistem dinamik, yang nantinya akan memberikan solusi serta manfaat untuk mendukung dalam pembuatan kebijakan dalam hal pengembangan smart economy di Kota Surabaya secara berkelanjutan.

\section{DASAR TEORI}

\section{A. Smart Economy}

Smart economy merupakan salah satu dimensi dalam konsep smart city yang didalamnya berisi seluruh aspek dalam perekonomian makro kota. Smart economy adalah suatu konsep dimana individu dalam suatu kota/daerah bisa hidup secara bebas dan bisa menentukan jalan hidupnya sendiri untuk berkontribusi terhadap perekonomian kota. Pencapaian dari smart economy berasal dari ketenagakerjaan dan angka kemiskinan dalam suatu kota [7]. Dan dalam lingkup yang lebih luas, kemiskinan dipengaruhi oleh kesejahteraan masyarakat. Kesejahteraan di kota Surabaya direpresentasikan oleh Indeks Pembangunan Manusia (IPM) dan Tingkat Pengangguran Terbuka (TPT) [11]. Hal lain yang mempengaruhi kemiskinan adalah produktivitas suatu kota yang direpresentasikan oleh Produk Domestik Regional Bruto (PDRB) [8].

\section{B. Kemiskinan}

Kemiskinan adalah ketidakmampuan orang untuk memenuhi kebutuhan ekonomi, sosial dan standar kebutuhan yang lain. Standar tingkat hidup yang rendah juga bisa dikatakan sebagai kemiskinan. Yaitu adanya tingkat kekurangan materi sejumlah atau golongan orang dibandingkan dengan standar kehidupan yang umum berlaku dalam masyarakat [12]. Menurut Kartasasmita, faktor penyebab kemiskinan terdapat empat, yaitu rendahnya taraf pendidikan, rendahnya derajat kesehatan, terbatasnya lapangan kerja, dan kondisi keterisolasian.

Ekonomi makro sangat berdampak pada jumlah kemiskinan yang didalamnya terdapat kesejahteraan masyarakat. Kesejahteraan masyarakat di kota Surabaya diukur dari indikator-indikator diantaranya Indeks Pembangunan Manusia (IPM) dan Tingkat Pengangguran Terbuka (TPT) [11].

\section{Ketenagakerjaan}

Penduduk terdiri dari penduduk usia kerja dan penduduk bukan usia kerja. Penduduk usia kerja adalah penduduk usia 15 tahun ke atas. Sedangkan penduduk bukan usia kerja adalah penduduk usia di bawah 15 tahun. Lalu penduduk usia kerja terdiri dari angkatan kerja dan bukan angkatan kerja. Angkatan kerja adalah penduduk usia kerja yang bekerja, atau punya pekerjaan namun sementara tidak bekerja atau mencari pekerjaan dan pengangguran. Angkatan kerja didapatkan dari jumlah pengangguran dan penjumlahan angkatan kerja tertampung. Sedangkan, penduduk yang termasuk bukan angkatan kerja adalah usia kerja yang masih sekolah, mengurus rumah tangga atau melaksanakan kegiatan lainnya [13].

\section{Produk Domestik Regional Bruto}

Produk Domestik Regional Bruto adalah jumlah nilai tambah yang dihasilkan oleh seluruh unit usaha dalam suatu negara tertentu, atau jumlah nilai akhir dari barang dan jasa yang dihasilkan oleh seluruh unit dan sektor ekonomi. PDRB merupakan salah satu indikator penting untuk mengetahui kondisi perekonomian di suatu wilayah/regional dalam suatu periode tertentu. PDRB biasanya disajikan dalam periode tahunan [14].

Terdapat 3 pendekatan yang digunakan untuk menghitung angka PDRB, yaitu pendekatan produksi, pendekatan pendapatan dan pendekatan pengeluaran. Pada penelitian ini menggunakan perhitungan PDRB berdasarkan pendekatan pengeluaran. PDRB pendekatan pengeluaran merupakan semua komponen permintaan akhir pengeluaran suatu wilayah yang meliputi konsumsi rumah tangga, pengeluaran pemerintah, investasi dan net ekspor.

\section{E. Indeks Pembangunan Manusia}

IPM merupakan indikator kesejahteraan rakyat yang digunakan oleh semua negara yang telah ditentukan oleh UNDP (United Nations Development Programme). IPM adalah suatu indeks yang mencerminkan kemampuan dari manusia itu sendiri [15].

Terdapat 3 dimensi yang diukur dalam IPM yaitu kesehatan, pendidikan, dan pendapatan. Indikator indeks dimensi kesehatan adalah usia harapan hidup yang mewakili umur 
panjang dan sehat. Indikator indeks dimensi pendidikan terdiri dari dua, yaitu angka melek huruf dan rata-rata lama sekolah. Sedangkan indikator indeks pendapatan adalah daya konsumsi per kapita yang mewakili kehidupan layak. Berikut indikator dan perhitungan teknis IPM yang ditetapkan oleh UNDP (United Nations Development Programme) [15].

\section{F. Konsep Model dan Simulasi}

Simulasi mengacu kepada kumpulan dari metode dan aplikasi untuk meniru perilaku dari sistem yang sebenarnya tanpa perlu membuat sistem yang asli yang dapat menguras banyak sumber daya, simulasi bisa diterapkan dalam berbagai macam bidang, industri dan aplikasi. Simulasi dapat dilakukan pada sistem yang simple maupun yang lebih kompleks, juga dapat membantu dalam pengambilan keputusan yang tepat dalam waktu yang singkat tanpa harus mengeluarkan biaya yang besar [16].

\section{G. Sistem Dinamik}

Sistem dinamik adalah suatu metode analisis permasalahan dimana waktu merupakan salah satu faktor penting, dan meliputi pemahaman bagaimana suatu sistem dapat dipertahankan dari gangguan di luar sistem, atau dibuat sesuai dengan tujuan dari pemodelan sistem yang akan dibuat [17].

\section{H. Analisis Regresi Double Log}

Analisis regresi adalah analisa yang menggunakan formula matematis untuk menunjukkan hubungan keterkaitan antar variabel-variabel. Variabel pada analisis regresi terdir dari dua kategori, yaitu variabel dependen dan variabel independen. Hasil dari perhitungan korelasi dapat dilihat pada $\mathrm{R}^{2}$. Semakin tinggi nilainya maka mengindikasikan besar hubungan dependen dengan nilai statistika. Jika nilainya positif maka memiliki hubungan yang positif, begitu pun sebaliknya [18].

Tabel 1.

Contoh Nilai Elastisitas Tenaga Kerja terhadap PDRB

\begin{tabular}{lll}
\hline \multicolumn{1}{c}{$\begin{array}{c}\text { Elastisitas lapangan } \\
\text { kerja }\end{array}$} & \multicolumn{3}{c}{$\begin{array}{c}\text { Pertumbuhan PDRB } \\
\text { positif }\end{array}$} & \multicolumn{1}{c}{ negatif } \\
\hline$\varepsilon<0$ & $(-) \quad$ pertumbuhan & $(+)$ pertumbuhan \\
& tenaga kerja & tenaga kerja \\
$0 \leq \varepsilon \leq 1$ & $(+) \quad$ pertumbuhan & $(-) \quad$ pertumbuhan \\
& tenaga kerja & tenaga kerja \\
& $(+) \quad$ pertumbuhan & $(-)$ pertumbuhan \\
& tenaga kerja & tenaga kerja \\
\hline \hline
\end{tabular}

Nilai koefisien elastisitas tenaga kerja pada Tabel 1 menunjukkan bahwa kenaikan 1\% PDRB akan menaikkan pertumbuhan ketenagakerjaan sebesar nilai koefisien elastisitas tenaga kerja dalam bentuk persen.

\section{METODOLOGI}

Pengerjaan penelitian ini tersusun atas beberapa langkah yang sistematis. Langkah-langkah pengerjaan penelitian dari awal hingga akhir ditunjukkan pada Gambar 1.

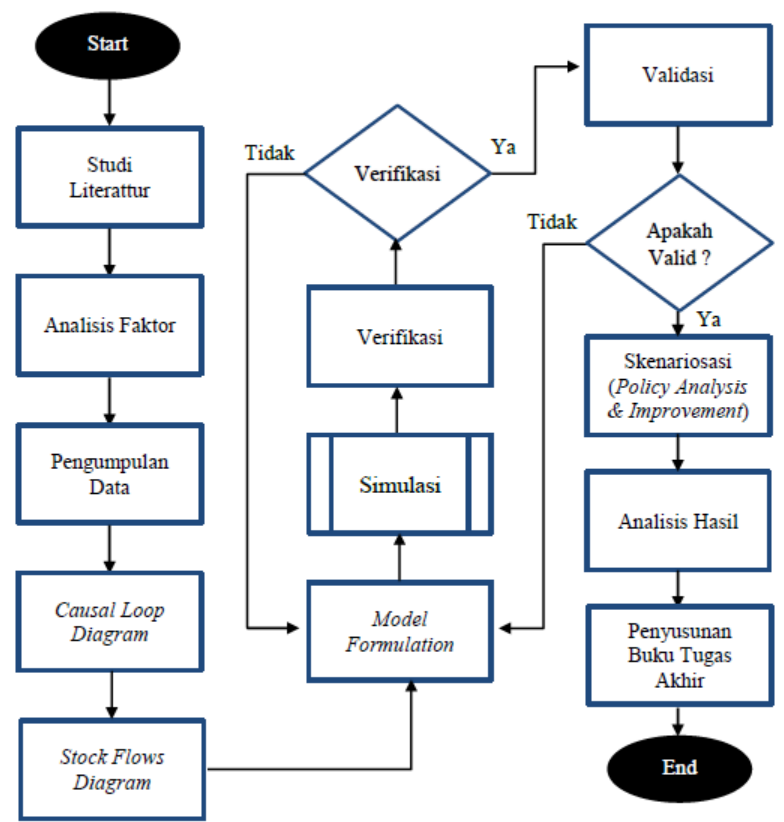

Gambar 1. Metodologi Penelitian

\section{MODEL DAN IMPLEMENTASI}

\section{A. Perancangan Model}

Dengan menggunakan metode simulasi sistem dinamik ini dibagi menjadi beberapa tahapan sebagai berikut:

a. Pembuatan Causal Loop Diagram

b. Pembuatan Stock Flow Diagram

c. Verifikasi dan validasi model

d. Pembuatan skenario

Pemodelan dan simulasi pada penelitian ini digunakan untuk memodelkan smart economy di kota Surabaya. Dilakukan pemodelan terhadap jumlah penduduk miskin dan pengangguran sebagai indikator smart economy, serta variabel pendukung lainnya. Sehingga hasil simulasi dapat membantu dalam pengembangan smart economy yang lebih optimal.

\section{B. Causal Loop Diagram}

Langkah awal dalam pembuatan simulasi sistem dinamik adalah dengan merumuskan model sesuai dengan kondisi existing dari perekonomian kota Surabaya. Yang paling utama dalam pembuatan konsep Causal Loop Diagram (CLD) adalah dengan melakukan identifikasi serta mneghubungkan antar masing-masing variabel yang berpengaruh terhadap pengembangan smart economy di kota Surabaya berdasarkan sistem perekonomian di kota Surabaya dan literatur terkait smart economy. Gambar 2 merupakan gambar diagram kausatik. 


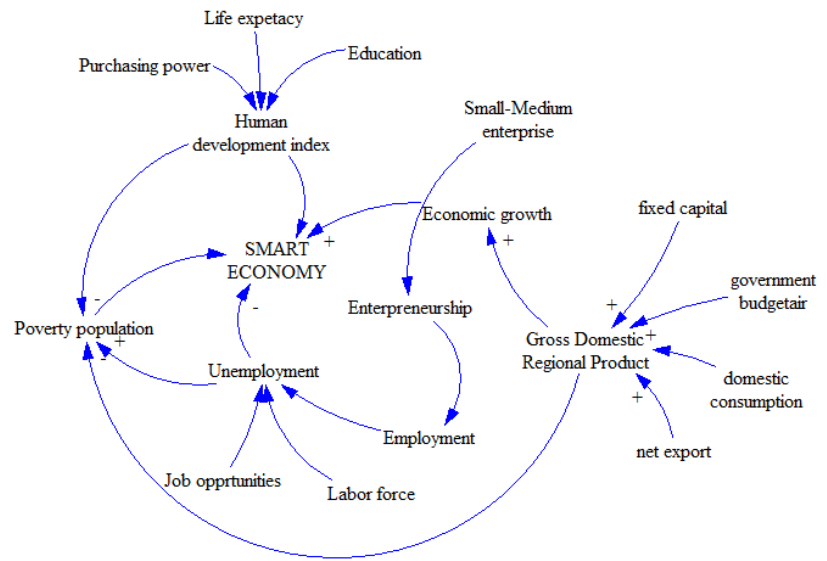

Gambar 2. Causal Loop Diagram dari Smart Economy

\section{Stock Flow Diagram}

Pemodelan data dan pembuatan flow diagram dibagi menjadi beberapa sub model. Pemodelan data dilakukan untuk mengetahui pola perilaku dan hubungan antar variabel yang ada pada simulasi untuk menentukan kesesuaian model dengan perilaku di kondisi nyata. Implementasi dari permodelan data digambarkan dari diagram kausatif. Setelah membuat diagram kausatif, selanjutnya flow diagram yang akan memudahkan dalam menggambarkan pemodelan skenario. Berikut merupakan implementasi dari pembuatan flow diagram:

a. Sub-Model PDRB (Gambar 3)

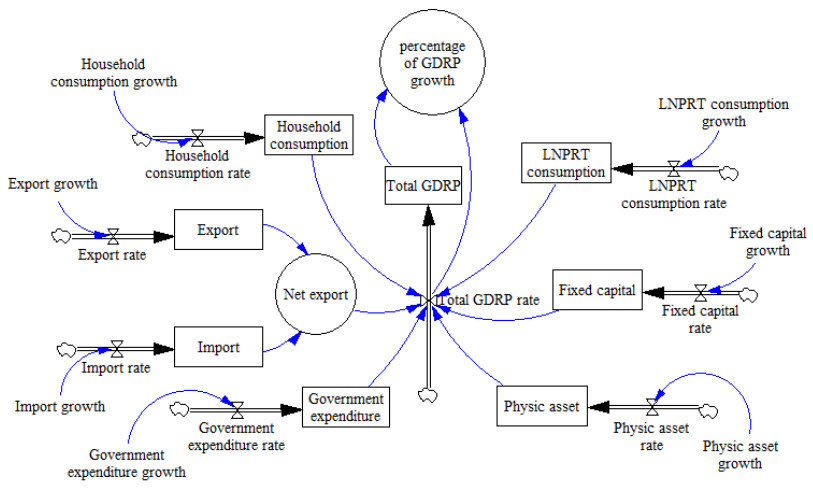

Gambar 3. Sub-Model PDRB

D. Sub-Model IPM (Gambar 4)

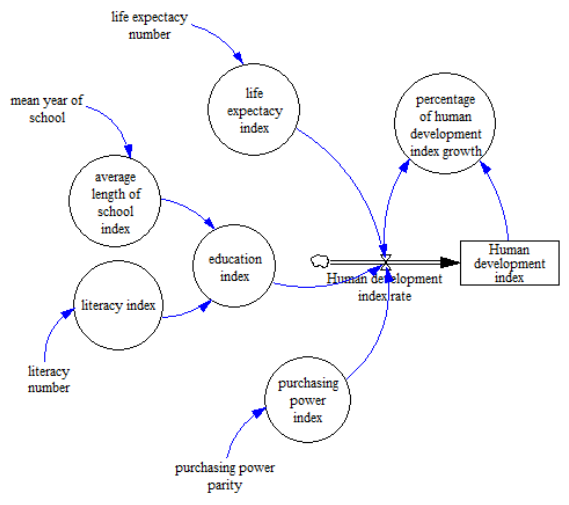

Gambar 4. Sub-Model IPM b. Sub-Model Kemiskinan (Gambar 5)

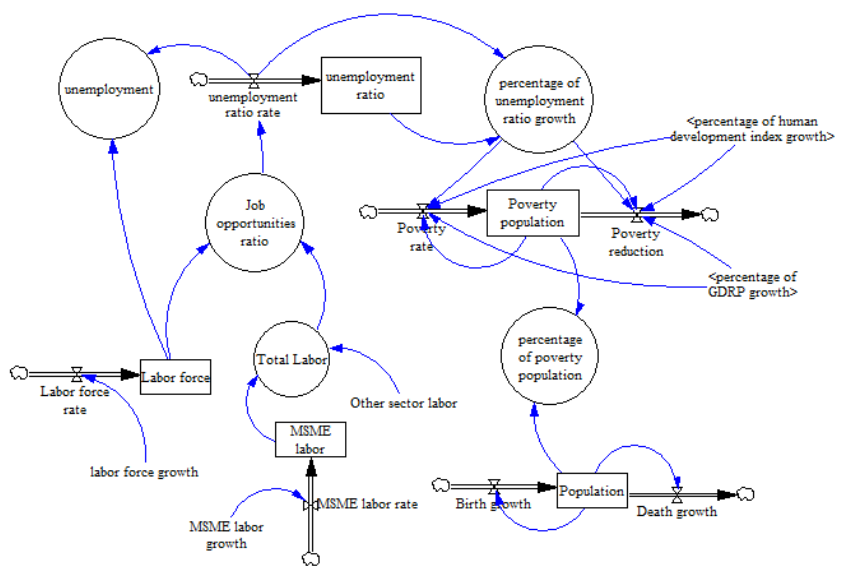

Gambar 5. Sub Model Kemiskinan

Berdasarkan penelitian sebelumnya, untuk mengetahui korelasi antara jumlah kemiskinan dengan PDRB, IPM dan pengangguran, maka dilakukan analisis regresi double log. Pada analisis regresi double log kali ini, jumlah penduduk miskin menjadi variabel dependen. Sedangkan untuk PDRB, IPM dan jumlah pengangguran menjadi variabel independen. Tabel 2 menunjukkan nilai korelasi dan elastisitas antar variabel dependen dan independen yang telah dimasukkan.

Tabel 2.

Hasil Analisis Regresi Variabel Penduduk Miskin

\begin{tabular}{lc}
\hline \hline$R$ Square & 0.868 \\
Adjusted $R$ Square & 0.835 \\
X Variabel Pengangguran & 0.636 \\
$X$ Variabel IPM & -0.602 \\
$X$ Variabel PDRB & -0.658 \\
\hline \hline
\end{tabular}

\section{E. Verifikasi dan Validasi}

Verifikasi model bertujuan untuk memastikan bahwa program komputer dan implementasi dari model konseptual tidak terjadi bug atau error. Pada tahap verifikasi ini akan dilakukan checking pada program computer dan implementasinya. Maka pada program vensim, proses verifikasi dilakukan ketika model sudah bisa dijalankan atau running. Validasi model bertujuan untuk memastikan apakah output perilaku dari model sudah akurat, sesuai kenyataan dan dapat diterima. Dengan cara behavior pattern test yaitu membandingkan hasil rata-rata dan variansi amplitude. Model dikatakan valid ketika perbandingan hasil rata-rata $<5 \%$ dan variansi amplitude $<30 \%$. Hasil validasi ditunjukkan pada Tabel 3.

Tabel 3. Hasil Uji Validasi

\begin{tabular}{ccc}
\hline \hline Variabel & Mean Comparison & Error Variance \\
\hline PDRB & $4.9 \%$ & $7.69 \%$ \\
IPM & $4.5 \%$ & $21.5 \%$ \\
Kemiskinan & $4.2 \%$ & $11.49 \%$ \\
\hline \hline
\end{tabular}

\section{PEMBUATAN SKENARIO DAN ANALISIS HASIL}

Setelah data hasil simulasi pada base model valid dengan data asli, maka selanjutnya adalah melakukan tahap pengembangan skenario. Terdapat 2 jenis skenario pada simulasi sistem, yaitu skenario struktur dan skenario parameter. Skenario struktur 
adalah skenario yang dilakukan dengan merubah struktur model pada variabel-variabel yang paling berpengaruh terhadap tujuan simulasi. Sedangkan pengembangan skenario parameter dilakukan dengan merubah parameter variabel-variabel penting untuk mengetahui kemungkinan keadaan di masa mendatang, baik secara optimis, pesimis, maupun keadaan yang rata-rata terjadi.. Skenario yang dibuat bertujuan untuk menurunkan angka kemiskinan di kota Surabaya dari beberapa faktor yang memperngaruhi. Berikut skenario yang telah dibuat:

a. $\quad$ Skenario Struktur 1 - Jenjang Pendidikan Tinggi

Dengan menambahkan rata-rata lama sekolah untuk penduduk jenjang pendidikan tinggi (S2 dan S3). Sehingga bisa meningkatkan nilai dari Indeks Pembangunan Manusia (lihat Gambar 6).

b. Skenario Struktur 2 - Investasi

Investasi swasta dapat menjadi stimulan untuk membuka lapangan kerja baru. Sehingga investasi dapat meningkatkan kesempatan kerja dan menurunkan tingkat pengangguran terbuka (lihat Gambar 7).

c. Skenario Parameter 1-Optimistic

Mengubah nilai pada variabel yang berpengaruh ke nilai pertumbuhan maksimum.

d. Skenario Parameter 2-Most Likely

Mengubah nilai pada variabel yang berpengaruh ke nilai pertumbuhan rata-rata.

e. Skenario Parameter 3 - Pesimistic

Mengubah nilai pada variabel yang berpengaruh ke nilai pertumbuhan minimum.

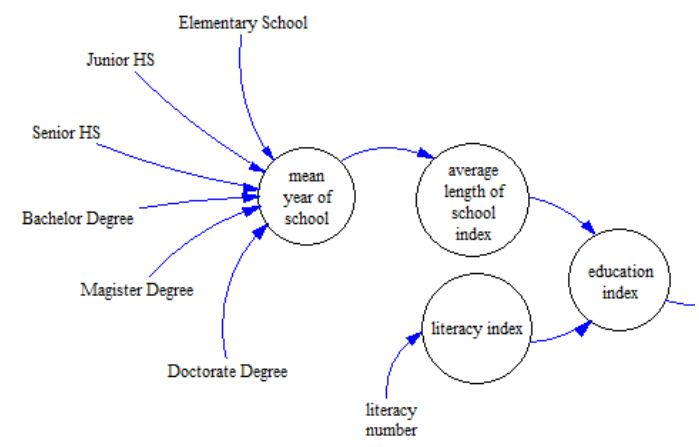

Gambar 6. Skenario Struktur 1 - Jenjang Pendidikan Tinggi

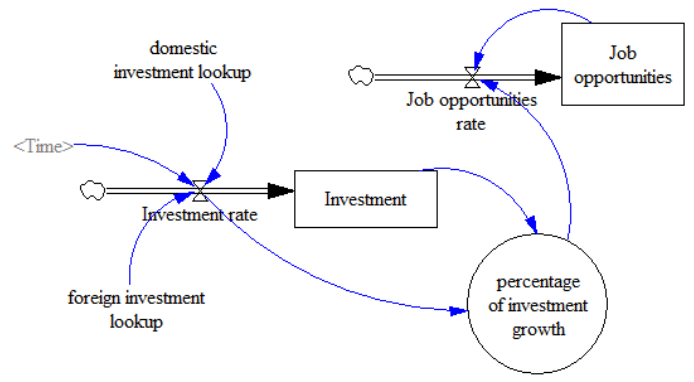

Gambar 7. Skenario Struktur 2 - Investasi
Hasil dari skenariosasi yang telah dilakukan tergambar pada grafik yang ada pada Gambar 8, Gambar 9, dan Tabel 4, sebagai berikut:

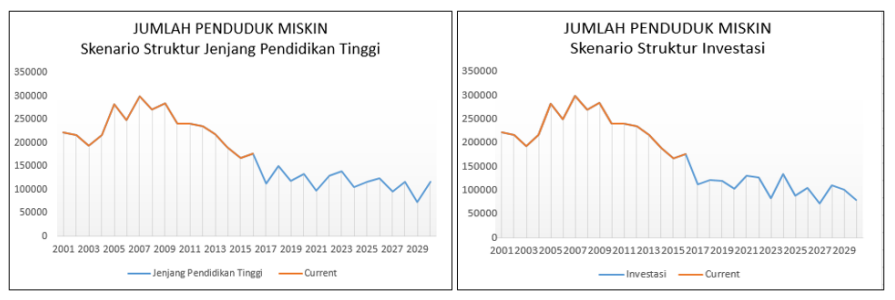

Gambar 8. Grafik Penduduk Miskin - Skenario Struktur

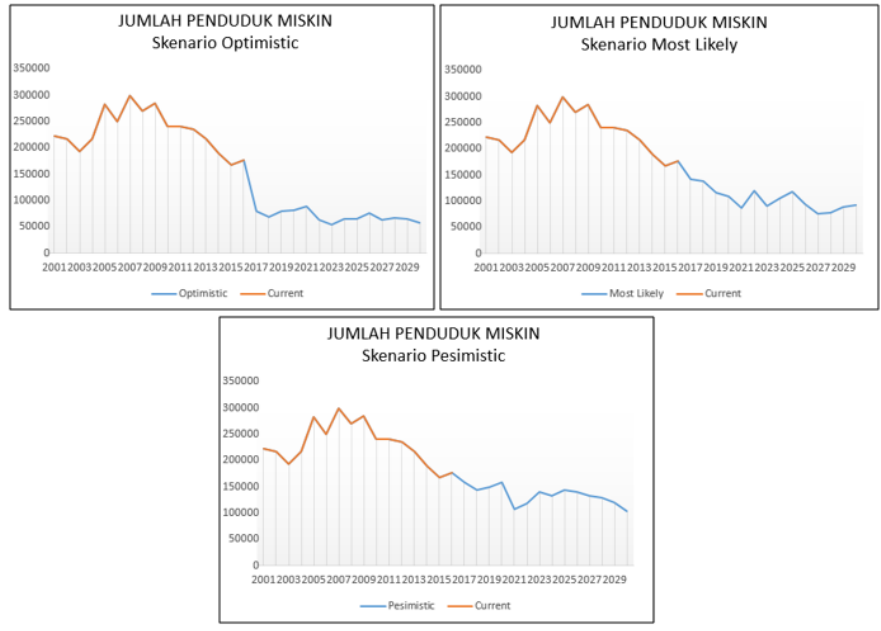

Gambar 9. Grafik Penduduk Miskin - Skenario Parameter

Tabel 4.

Hasil Skenario

\begin{tabular}{lc}
\hline \hline \multicolumn{1}{c}{ Skenario } & $\begin{array}{c}\text { Rata-rata Penduduk Miskin } \\
\text { (Jiwa) }\end{array}$ \\
\hline Struktur - Jenjang Pendidikan Tinggi & 177584 \\
Struktur - Investasi & 173146 \\
Parameter - Optimistic & 155941 \\
Parameter - Most Likely & 171876 \\
Parameter - Pesimistic & 185871 \\
\hline \hline
\end{tabular}

\section{KESIMPULAN}

Berdasarkan hasil penelitian, berikut ini merupakan beberapa kesimpulan yang dapat diambil:

1. Indikator perekonomian yang berpengaruh terhadap pertumbuhan kemiskinan adalah Tingkat Pengangguran Terbuka (TPT) dengan nilai elastisitas sebesar 0.636, Indeks Pembangunan Manusia (IPM) dengan nilai elastisitas sebesar -0.602, dan Produk Domestik Regional Bruto (PDRB) dengan nilai elastisitas sebesar -0.658. Dengan demikian ketiga indikator tersebut memiliki korelasi yang cukup tinggi dengan angka kemiskinan.

a. Tingkat Pengangguran Terbuka (TPT)

Koefisien variabel TPT menunjukkan bahwa tiap kenaikan $1 \%$ nilai TPT, maka menaikkan $0.636 \%$ jumlah penduduk miskin.

b. Indeks Pembangunan Manusia (IPM) 
Koefisien variabel IPM menunjukkan bahwa tiap kenaikan $1 \%$ nilai IPM, maka menurunkan $0.602 \%$ jumlah penduduk miskin.

c. Produk Domestik Regional Bruto (PDRB)

Koefisien variabel TPT menunjukkan bahwa tiap kenaikan $1 \%$ nilai TPT, maka menurunkan $0.658 \%$ jumlah penduduk miskin.

2. Model yang dibuat pada Studi ini telah valid dan sesuai dengan sistem nyata. Karena sudah melalui uji validitas dengan syarat Means Comparison (E1) < 5\%, dan Amplitudo Variance Comparison (E2) < 30\%. Sehingga model simulasi sistem ini bisa menjadi referensi untuk menentukan kebijakan terkait smart economy di kota Surabaya. Dan model ini bisa menjadi acuan untuk melakukan simulasi smart economy yang indikator utamanya adalah penurunan penganggutan dan jumlah penduduk miskin.

3. Skenario dibuat untuk dapat memberikan rekomendasi atau usulan terkait perbaikan sistem. Skenario yang dibuat adalah skenario struktur dan parameter. Skenario struktur meliputi penambahan variabel jenjang pendidikan tinggi untuk indeks pendidikan pada IPM, dan penambahan variabel investasi yang akan mempengaruhi kesempatan kerja. Dan skenario parameter meliputi skenario optimistic, most likely, dan pesimistic.

4. Dari hasil skenariosasi yang telah dilakukan, dapat disimpulkan bahwa:

a. Skenario struktur yang paling dapat mengurangi ratarata Tingkat Pengangguran Terbuka adalah skenario struktur variabel investasi, yaitu sebesar 7.75. Sedangkan skenario parameter yang paling dapat mengurangi rata-rata Tingkat Pengangguran Terbuka adalah skenario optimistic, yaitu sebesar 8.23.

b. Skenario struktur yang paling dapat mengurangi ratarata jumlah penduduk miskin adalah skenario struktur variabel investasi, yaitu sebesar 173146 jiwa. Sedangkan skenario parameter yang paling dapat mengurangi ratarata jumlah penduduk miskin adalah skenario optimistic, yaitu sebesar 155941 jiwa.

c. Skenario struktur yang paling dapat mengurangi ratarata persentase penduduk miskin terhadap populasi adalah skenario struktur variabel investasi, yaitu sebesar $6.24 \%$. Sedangkan skenario parameter yang paling dapat mengurangi rata-rata persentase penduduk miskin adalah skenario optimistic, yaitu sebesar $5.62 \%$.

5. Berdasarkan perbandingan dari skenario struktur dan skenario parameter, dapat diambil kesimpulan bahwa skenario yang dapat mengurangi rata-rata Tingkat Pengangguran Terbuka adalah skenario struktur variabel investasi. Sedangkan skenario yang dapat mengurangi ratarata jumlah dan persentase penduduk miskin adalah skenario parameter optimistic.

\section{SARAN}

Berdasarkan kesimpulan hasil penelitian, adapun saran yang dapat digunakan dalam perbaikan atau penelitian selanjutnya, yaitu:
1. Untuk penelitian lebih lanjut, perlu dilakukan pemodelan dengan mengintegrasikan sistem dari dimensi smart city yang lainnya.

2. Perlu ditelaah jauh indikator-indikator performa ekonomi makro lainnya dan juga ekonomi mikro yang dapat mempengaruhi pengangguran dan kemiskinan di kota Surabaya, contoh pelatihan UMKM, kebijakan pajak investasi, inflasi, dan lain-lain

3. Pengembangan model perekonomian kota dengan mempertimbangkan PDRB dari 2 metode yang lain. Yaitu metode pendapatan dan metode berdasarkan lapangan usaha.

4. Wawasan terkait sistem dinamik serta teknis penggunaan aplikasinya agar didapatkan model yang akurat dengan struktur dan persamaan yang valid di dalamnya. Sehingga bisa memberikan solusi terkait sistem yang lebih baik kedepannya.

\section{DAFTAR PUSTAKA}

[1] S. Community, F. Smart, and C. Indonesia, "Smart city id," vol. I, pp. 2-7, 2015.

[2] R. Giffinger, "Smart cities Ranking of European medium-sized cities," October, vol. 16, no. October, pp. 13-18, 2007.

[3] P. K. Surabaya, "Surabaya Raih 3 dari 4 Kategori Penghargaan di Ajang Smart City Award 2011," 2011.

Indonesia International Smart City Expo, "No Title," 2016. .

[5] B. K. Surabaya, Kota Surabaya Dalam Angka 2016. BPS Kota Surabaya, 2016.

[6] D. Apostol, C. Bălăceanu, and E. M. Constantinescu, "SMARTECONOMY CONCEPT - FACTS AND PERSPECTIVES,” pp. 1-8.

[7] S. C. Council, "Dissecting ISO 37120: Economic indicators in the new smart city standard," 2014.

[8] G. Veldhuis, P. Van Scheepstal, and N. Vink, "Development of a generic Smart City model using MARVEL," 2014.

[9] B. K. Surabaya, Statistik Daerah Kota Surabaya. Surabaya: BPS Kota Surabaya, 2016.

[10] P. K. Surabaya, Laporan Keterangan Pertanggungjawaban Kepala Daerah. Surabaya, 2016.

[11] BAPPEKO, Rencana Pembangunan Jangka Menengah Daerah Kota Surabaya 2016-2021. Surabaya, 2016.

P. Herbert, The DAC Guidelines Poverty Reduction. OECD, 2001. BPS, "Konsep Metodologi.".

B. K. Surabaya, "Produk Domestik Regional Bruto," Surabaya, 2014. BPS, “Indeks Pembangunan Manusia 2013," Jakarta, 2013.

W. D. Kelton and R. P. Sadowski, "Simulating with ARENA.” p. 547, 1998

R. G. Coyle, System Dynamic Modelling. Chapman, 1996.

[18] S. Kapsos, "The Employment Intensity of Growth: Trends and Macroeconomic Determinants," 2005. 